(c) American Dairy Science Association, 2004.

\title{
Performance of Holstein Clones in the United States
}

\author{
H. D. Norman, ${ }^{1}$ T. J. Lawlor, ${ }^{2}$ J. R. Wright, ${ }^{1}$ and R. L. Powell ${ }^{1}$ \\ ${ }^{1}$ Animal Improvement Programs Laboratory, \\ Agricultural Research Service, USDA, \\ Beltsville, MD 20705-2350 \\ ${ }^{2}$ Holstein Association USA, \\ Brattleboro, VT 05302
}

\section{ABSTRACT}

Phenotypic and genetic performance of US Holstein clones from embryo splitting (ETS) and nuclear transfer (ETN) was documented for yield and fitness traits. Holstein Association USA has registered 2319 ETS and 215 ETN clones. The number of male clones has decreased. Animals selected for cloning were slightly superior genetically to population mean for yield traits. For females, mean superiority of pedigree merit of ETS clones was $186 \mathrm{~kg}$ for milk, $9 \mathrm{~kg}$ for fat, and $7 \mathrm{~kg}$ for protein compared with the population for the same birth year; for ETN clones, superiority to the population was 165, 10 , and $8 \mathrm{~kg}$. Advantage in pedigree merit for male clones generally was slightly greater. The small pedigree advantage for female clones of $<1$ standard deviation above breed mean indicates that selection of animals to clone was not based primarily on yield. Yield deviations were lower for ETS clones than for their full siblings, which indicates a possible impact of the technology on performance. Yields were lower for ETN clones than for their noncloned full siblings, but differences were small and based on small numbers of clones. Milk composition for cloned cows was not different from that for the population. Estimated genetic merit based on daughter yield was more similar for male clone pairs with apparent identical genotype than for clone pairs from the same biotechnology but nonidentical as confirmed by blood typing. For ETS clones with confirmed identical genotypes, identical genetic merit should be assigned.

(Key words: clone, embryo splitting, nuclear transfer, yield performance)

Abbreviation key: DPR = daughter pregnancy rate, ETN = embryo transfer with nuclear transfer, ETS = embryo transfer with embryo splitting, PA = mean of parent PTA, $\mathbf{P L}=$ productive life.

Received December 31, 2002.

Accepted June 11, 2003.

Corresponding author: H. D. Norman; e-mail: dnorman@aipl. arsusda.gov.

\section{INTRODUCTION}

Interest in the impact of biotechnology on food safety led the National Research Council (Committee on Defining Science-Based Concerns Associated with Products of Animal Biotechnology, 2002) in the United States to establish a subcommittee to identify and to prioritize science-based risks of genetically modified animals. Based on that subcommittee's report, the US Food and Drug Administration (Center for Veterinary Medicine, 2001) will decide how cloned animals should be regulated. Consequently, the Food and Drug Administration requested that ARS, USDA, examine the performance of dairy cattle clones.

The cloning technologies of embryo splitting (Willadsen, 1979) and nuclear transfer (Robl et al., 1987) were introduced to dairy cattle breeding in the $1980 \mathrm{~s}$. Embryo transfer with embryo splitting (ETS) is a process by which an embryo is extracted from the donor and split by surgical bisections (usually in two but sometimes in four segments); the demi-embryos are transferred into recipients with reproductive cycles that have been synchronized with that of the donor. To date, the performance of ETS animals has not been reviewed; conventional wisdom suggests that those clones should perform like animals from normal births. A similar splitting process can take place in nature within 8 to $10 \mathrm{~d}$ after conception and results in the development of identical (monozygotic) twins. In nature's case, the twins are carried by the same cow, and multiple births have been shown to influence performance of cow and calves (Echterncamp and Gregory, 2002). With bisection, most ETS calves are delivered as single births because the reduced-cell embryos usually are transferred into different recipients so that the disadvantages of multiple births are avoided.

In the late $1980 \mathrm{~s}$, Robl et al. (1987) outlined how to create several animals from a single embryo using a nuclear transfer process. For embryo transfer with nuclear transfer (ETN), a donor embryo is collected, and the nucleus (with nuclear DNA) from each cell is transferred to a recipient cell that has had the nucleus removed. If transferred to a recipient, each of the new 
embryos can develop into a different animal to produce a clonal family.

The unresolved question is how close the genotypes of ETN animals are to being identical. Although such clones are expected to have identical nuclear DNA, their mitochondrial DNA differs. Unfortunately, little information has been recorded on the identity of the recipient cells used in the nuclear transfer process; most recipient cells have been obtained from slaughter houses. The uncertain genetic composition of ETN animals contributes to differing views on whether their genetic evaluations should be the same or allowed to differ by assuming that ETN animals are full siblings rather than identical in calculating genetic indexes. To determine whether animals have identical nuclear DNA requires additional steps with some expenses. Two methods of accomplishing this are blood and DNA typing. Results from either process could be used to indicate which twins sets were likely identical. At present, the Animal Improvement Programs Laboratory, USDA (Beltsville, MD), does not combine information for animals with identical genotypes when computing genetic evaluations; instead, those animals are treated as full siblings because the blood or DNA information needed to assume identical genotypes generally has not been available. Concern also continues about developmental aspects of clones (Young et al., 1998), which could impact yield and fitness traits.

Holstein Association USA (Brattleboro, VT) first registered calves from ETS in 1982 and from ETN in 1989. Both of those technologies caused excitement in the industry because each provided another opportunity to increase the number of progeny from individuals that were perceived to be outstanding. Prior to those two technologies, selected propagation was accelerated through AI as well as through embryo transfer, usually with superovulation. Blood typing is required by Holstein Association USA for 1) all heifers that resulted from embryo transfer and were born before July 1, 1992, 2 ) all bulls that resulted from embryo transfer and were born before July 1, 1988, 3) all donor dams, 4) all bulls that were progeny tested through AI, and 5) all ETN animals. Consequently, many ETS animals and all ETN animals now have blood typing information available. Holstein Association USA also requires that an International Embryo Transfer Society embryo recovery form (available online: http://www.iets.org/pdf/ Freeze_code/ab.pdf; accessed Dec. 11, 2003) be submitted for all registered animals that resulted from embryo transfer. This certificate cross-references individual animals to the "recovery" or "flush" from which the embryo was retrieved.

Individuals selected for cloning need to be superior for genetic merit for milk and component yields, or they likely will not contribute appreciably to genetic improvement. Nevertheless, their selection may have been based on other traits that have lower economic value, such as show ring success or certain fitness traits. An examination within clonal families is needed to verify that performance is as expected from identical genotypes; i.e., the mean and variance for the progeny of clones are the same as expected for separate progeny sets of the same animal. If members of a clonal family are identical or nearly so, information from all progeny could be merged to produce a genetic evaluation for the group that would be more accurate than those calculated separately based on records from progeny from only one individual. Objectives of this study were to document the number of US Holstein ETS and ETN animals, to examine the mean PTA of their parents to determine the criteria for their selection, and to summarize phenotypic and genetic values of clones for yield, SCS, productive life (PL), and daughter pregnancy rate (DPR) to determine whether clones perform as expected.

\section{MATERIALS AND METHODS}

Numbers of ETS and ETN animals registered with Holstein Association USA were documented by gender and birth year. Pedigree merit calculated as mean of parent PTA (PA) for yield traits (milk, fat, and protein) for the clones was compared with genetic merit (PTA) of all US milk-recorded Holsteins that were born in the same year to determine whether the cattle that produced the clones were superior to the population for yield traits.

To make an equitable comparison of the effects of cloning technology, means for each clone group were calculated for phenotypic and genetic measures of milk, fat, and protein yields as well as of SCS, PL, and DPR, a newly evaluated fertility trait (VanRaden et al., 2002). Those means were compared with trait means for noncloned full siblings.

Although Holstein Association USA identifies ETS and ETN animals, those animals cannot be assumed to have originated from the same embryo; i.e., to be clones. Two or more embryos from the flush (or even different flushes) may have been split or subject to nuclear transfer, which raises the possibility that they are only full siblings. If only one calf developed from each of the multiple splits, those ETS animals would be full siblings in most cases and not identical.

Because of blood typing requirements of Holstein Association USA for registration, many ETS animals and all ETN animals had blood typing information available. Through examination of blood type files available at Holstein Association USA, ETS and ETN bulls were 

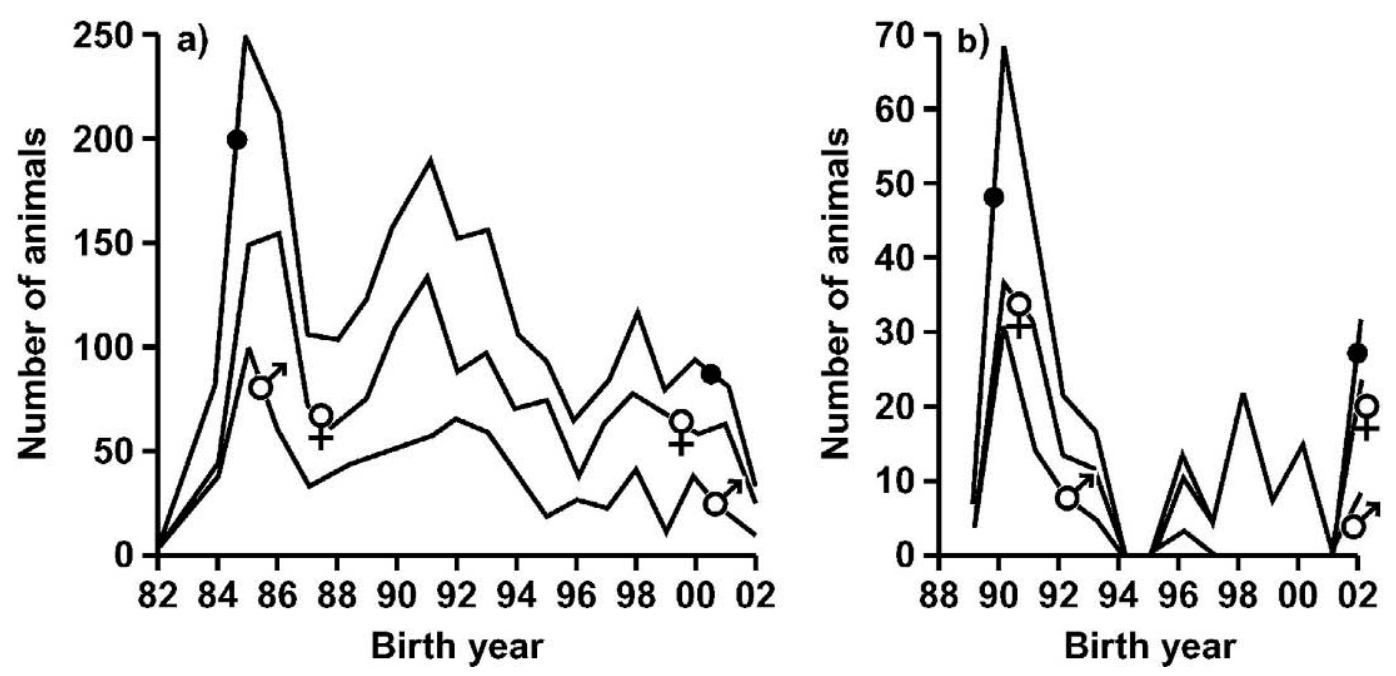

Figure 1. Numbers of registered US Holsteins resulting from a) embryo splitting or b) nuclear transfer by gender (all animals: $\bullet$, males: ô, females: $q$ ) and birth year.

categorized separately into two groups: those bulls with a high probability of being clones and those that definitely were not identical.

To identify pairs of ETS animals that were likely to have identical genotypes, the following criteria were applied: 1) both animals were recorded as originating from the same recovery or flush; 2) both animals were recorded as ETS; 3) both animals had the same blood type; and 4) both animals were of the same gender. Criteria 1 and 2 identify a group of animals that could be clones of one another. Criteria 3 and 4 identify those animals within a group that probably are clones of one another. Although two animals that are of the same gender, come from the same flush, and have the same blood type cannot be determined unequivocally to be clones of each other, the probability of detecting genetic differences that would indicate that a pair of ETS animals are not clones is $99.8 \%$ (see Appendix) based on the application of all four criteria.

A few of the ETN animals were from fetal or adult cells, but none of those yet had daughters with DHI lactation records. Differences in PTA for yield and fitness traits were summarized for pairs of ETS bulls that were likely to have identical genotypes as well as for pairs of ETS bulls that were not identical; i.e., full brothers. All bulls had to have a USDA-DHIA genetic evaluation and $\geq 10$ daughters with lactation records. Bulls also were required to have both parents with USDADHIA genetic evaluations. Most of the bulls had been used in $\mathrm{AI}$ and, therefore, had moderate reliabilities for their PTA.

\section{RESULTS AND DISCUSSION}

A total of 2319 ETS (1536 female and 783 male) Holstein clones had been registered with Holstein Association USA through October 2002 (Figure 1a). Number of ETS clones increased rapidly from 4 in 1982 to 246 in 1985. Since this early interest in embryo splitting, numbers have declined but only significantly $(P \leq 0.05$, linear and quadratic) for males. Observations from 1982 and 2002 were excluded from the regression analysis because they did not include data for a complete year. As scientific interest and subsidies in the technology waned and as the procedure was commercialized, yearly numbers of ETS clones became more uniform: mean number of splits annually were 60 females and 26 males from 1996 through 2001. The larger numbers of female ETS clones could indicate that embryos were split in conjunction with sexing or that some male ETS clones were not of enough interest to warrant breed registration. All ETS females born also may not have been registered with Holstein Association USA.

A total of 215 ETN (151 female and 64 male) Holstein clones had been registered with Holstein Association USA through October 2002 (Figure 1b). The most female (36) and male (31) ETN clones were born in 1990, the year after the first ETN clone was registered. Decreasing numbers of ETN clones were significant for males ( $P \leq 0.05$, both linear and linear-quadratic). The increase in ETN clones in 1999 reflects substantial activity with fetal cloning at one site. Interest in ETN clones has shifted toward females. Of the 60 animals that have been registered since 1995, only 3 were male. 
Table 1. Pedigree merit ${ }^{1}$ for yield traits of Holstein embryo-split clones ${ }^{2}$ by gender and genetic merit (PTA) of the milk-recorded Holstein population by birth year.

\begin{tabular}{|c|c|c|c|c|c|c|c|c|c|}
\hline \multirow[b]{3}{*}{ Birth year } & \multicolumn{6}{|c|}{ Embryo-split clones } & & & \\
\hline & \multicolumn{3}{|c|}{ Females } & \multicolumn{3}{|c|}{ Males } & \multicolumn{3}{|c|}{ Population } \\
\hline & Milk & Fat & Protein & Milk & Fat & Protein & Milk & Fat & Protein \\
\hline & & & & & $-\left(\mathrm{k}_{\xi}\right)$ & & & & \\
\hline 1983 & -695 & -24 & -20 & -735 & -24 & -23 & -634 & -22 & -18 \\
\hline 1984 & -436 & -14 & -13 & -689 & -19 & -21 & -591 & -20 & -17 \\
\hline 1985 & -406 & -13 & -13 & -488 & -15 & -16 & -544 & -19 & -16 \\
\hline 1986 & -435 & -13 & -13 & -479 & -18 & -15 & -496 & -17 & -15 \\
\hline 1987 & -391 & -9 & -11 & -471 & -14 & -15 & -450 & -15 & -13 \\
\hline 1988 & -300 & -4 & -7 & -388 & -6 & -10 & -396 & -12 & -12 \\
\hline 1989 & -265 & -2 & -6 & -398 & -4 & -9 & -337 & -10 & -10 \\
\hline 1990 & -109 & 1 & -1 & -12 & 8 & 2 & -287 & -8 & -8 \\
\hline 1991 & -51 & 2 & 1 & -66 & 4 & 1 & -228 & -7 & -7 \\
\hline 1992 & 67 & 5 & 6 & 191 & 8 & 9 & -168 & -5 & -5 \\
\hline 1993 & 99 & 5 & 6 & 188 & 12 & 10 & -111 & -3 & -3 \\
\hline 1994 & 81 & 8 & 5 & 368 & 18 & 5 & -57 & -2 & -2 \\
\hline 1995 & 98 & 7 & 5 & 390 & 15 & 17 & 0 & 0 & 0 \\
\hline 1996 & 230 & 7 & 9 & 380 & 17 & 15 & 61 & 2 & 2 \\
\hline 1997 & 411 & 13 & 15 & 786 & 20 & 28 & 120 & 3 & 4 \\
\hline 1998 & 481 & 15 & 17 & 973 & 27 & 34 & 177 & 5 & 5 \\
\hline 1999 & 438 & 15 & 15 & 1017 & 26 & 31 & 215 & 7 & 7 \\
\hline 2000 & 647 & 26 & 24 & 1136 & 40 & 37 & 253 & 8 & 8 \\
\hline 2001 & 878 & 32 & 28 & 1129 & 39 & 39 & & & $3^{3}$ \\
\hline \multicolumn{10}{|l|}{ All years ${ }^{4}$} \\
\hline Females & 9 & 3 & 2 & $\ldots$ & & . . & -177 & -6 & -5 \\
\hline Males & $\ldots$ & $\ldots$ & $\ldots$ & 32 & 4 & 3 & -222 & -7 & -6 \\
\hline
\end{tabular}

${ }^{1}$ Mean of parent PTA.

${ }^{2}$ Registered with Holstein Association USA (Brattleboro, VT).

${ }^{3}$ Population means not shown because of limited number of animals with reported lactation records.

${ }^{4}$ Means for 1420 female and 643 male embryo-split clones; population means include pedigree merit from 2000 for birth year 2001 and are weighted by number of clones of each gender in each year.

The decline in numbers of male clones has diminished their potential genetic impact on the population. Still, small numbers of ETS or ETN male clones are sufficient to impact the population genetically.

For embryo-transfer clones to enhance the population, their PA should be superior to the genetic merit of the population. Most of the female clones had parents with genetic evaluations (149 of 151 ETN clones and 1420 of 1536 ETS clones). Population means by gender across all years were weighted by number of clones of each gender in each year. For female ETS clones (Table 1), overall mean superiority of PA compared with population PTA for the same birth year was $186 \mathrm{~kg}$ for milk, $9 \mathrm{~kg}$ for fat, and $7 \mathrm{~kg}$ for protein $(P<0.001)$; for male ETS clones, corresponding superiority was 254,11 , and $9 \mathrm{~kg}(P<0.001)$. Comparisons between clones and the population were not tested for significance for individual years. For ETN female clones (Table 2), overall superiority of PA to population PTA was $165 \mathrm{~kg}$ for milk, $10 \mathrm{~kg}$ for fat, and $8 \mathrm{~kg}$ for protein $(P<0.01)$; for ETN male clones, corresponding superiority was 246 , 10 , and $9 \mathrm{~kg}(P<0.001)$. The small pedigree advantage for female clones of $<1$ standard deviation above breed mean for yield traits indicates that determining which animals to clone was not based exclusively on production.

Pedigree merit of clones that survived to calving and were enrolled in milk recording also was compared with genetic merit of the population. For 921 ETS females with milk records (Table 3), mean superiority of PA compared with population PTA for the equivalent birth year was $180 \mathrm{~kg}$ for milk, $8 \mathrm{~kg}$ for fat, and $7 \mathrm{~kg}$ for protein $(P<0.001)$; for 172 ETS males with PTA for yield, corresponding superiority was 314,13 , and $10 \mathrm{~kg}$ $(P<0.001)$. For 75 ETN females with milk records (Table 4), superiority of PA compared with population PTA was $207 \mathrm{~kg}$ of milk, $9 \mathrm{~kg}$ of fat, and $7 \mathrm{~kg}$ of protein $(P<0.001)$; for 11 ETN males, corresponding superiority was $335(P<0.001), 6(P<0.05)$, and $12 \mathrm{~kg}(P<$ $0.001)$. No difference in genetic superiority to the milkrecorded population was evident between registered female clones and those that survived to have lactation records.

Of the 1536 ETS female clones that have been registered since 1982, 608 had DHI yield records and noncloned full sisters with records available for comparison (mean of 1.7 full sisters per ETS clone). Differences between the 608 ETS clones and full sisters for stan- 
Table 2. Pedigree merit ${ }^{1}$ for yield traits of Holstein nuclear-transfer clones ${ }^{2}$ by gender and genetic merit (PTA) of the milk-recorded Holstein population by birth year.

\begin{tabular}{|c|c|c|c|c|c|c|c|c|c|}
\hline \multirow[b]{3}{*}{ Birth year } & \multicolumn{6}{|c|}{ Nuclear-transfer clones } & & & \\
\hline & \multicolumn{3}{|c|}{ Females } & \multicolumn{3}{|c|}{ Males } & \multicolumn{3}{|c|}{ Population } \\
\hline & Milk & Fat & Protein & Milk & Fat & Protein & Milk & Fat & Protein \\
\hline & \multicolumn{9}{|c|}{ - (kg) } \\
\hline 1989 & -111 & -3 & -2 & -148 & -15 & -6 & -337 & -10 & -10 \\
\hline 1990 & -43 & 5 & 0 & -163 & 1 & -2 & -287 & -8 & -8 \\
\hline 1991 & -62 & 2 & 0 & -21 & -4 & -2 & -228 & -7 & -7 \\
\hline 1992 & 108 & 8 & 3 & 654 & 21 & 20 & -168 & -5 & -5 \\
\hline 1993 & 27 & 7 & 6 & 53 & 15 & 6 & -111 & -3 & -3 \\
\hline 1994 & $\ldots$ & $\ldots$ & $\ldots$ & $\ldots$ & $\ldots$ & $\ldots$ & -57 & -2 & -2 \\
\hline 1995 & $\ldots$ & $\ldots$ & $\ldots$ & $\ldots$ & $\ldots$ & $\ldots$ & 0 & 0 & 0 \\
\hline 1996 & 256 & 14 & 13 & 508 & 17 & 23 & 61 & 2 & 2 \\
\hline 1997 & & & 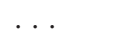 & $\ldots$ & $\ldots$ & $\ldots$ & 120 & 3 & 4 \\
\hline 1998 & 1262 & 24 & 42 & $\ldots$ & $\ldots$ & $\ldots$ & 177 & 5 & 5 \\
\hline 1999 & 589 & 12 & 21 & $\ldots$ & $\ldots$ & $\ldots$ & 215 & 7 & 7 \\
\hline 2000 & 303 & 14 & 19 & $\ldots$ & $\ldots$ & $\ldots$ & 253 & 8 & 8 \\
\hline 2001 & -402 & 11 & -1 & $\ldots$ & $\ldots$ & $\ldots$ & $\ldots 3^{3}$ & $\ldots .^{3}$ & $\ldots 3^{3}$ \\
\hline \multicolumn{10}{|l|}{ All years ${ }^{4}$} \\
\hline Females & 84 & 8 & 6 & $\ldots$ & $\ldots$ & $\ldots$ & -81 & -2 & -2 \\
\hline Males & $\ldots$ & $\ldots$ & $\ldots$ & 15 & 3 & 2 & -231 & -7 & -7 \\
\hline
\end{tabular}

${ }^{1}$ Mean of parent PTA.

${ }^{2}$ Registered with Holstein Association USA (Brattleboro, VT).

${ }^{3}$ Population means not shown because of limited number of animals with reported lactation records.

${ }^{4}$ Means for 149 female and 50 male embryo-split clones; population means include pedigree merit from 2000 for birth year 2001 and are weighted by number of clones of each gender in each year.

Table 3. Pedigree merit ${ }^{1}$ for yield traits of Holstein embryo-split clones ${ }^{2}$ with USDA-DHIA genetic evaluations by gender and genetic merit (PTA) of the milk-recorded Holstein population by birth year.

\begin{tabular}{|c|c|c|c|c|c|c|c|c|c|}
\hline \multirow[b]{3}{*}{ Birth year } & \multicolumn{6}{|c|}{ Embryo-split clones } & & & \\
\hline & \multicolumn{3}{|c|}{ Females } & \multicolumn{3}{|c|}{ Males } & \multicolumn{3}{|c|}{ Population } \\
\hline & Milk & Fat & Protein & Milk & Fat & Protein & Milk & Fat & Protein \\
\hline & & & & & $-(\mathrm{kg}$ & & & & \\
\hline 1983 & -477 & -14 & -13 & -294 & -13 & -15 & -634 & -22 & -18 \\
\hline 1984 & -359 & -11 & -10 & -351 & -9 & -10 & -591 & -20 & -17 \\
\hline 1985 & -275 & -9 & -10 & -224 & -8 & -9 & -544 & -19 & -16 \\
\hline 1986 & -297 & -8 & -8 & -63 & -2 & -5 & -496 & -17 & -15 \\
\hline 1987 & -314 & -8 & -9 & -182 & -3 & -6 & -450 & -15 & -13 \\
\hline 1988 & -237 & -3 & -6 & -289 & 0 & -5 & -396 & -12 & -12 \\
\hline 1989 & -208 & -2 & -4 & -212 & -2 & -5 & -337 & -10 & -10 \\
\hline 1990 & -75 & 1 & 0 & 114 & 7 & 6 & -287 & -8 & -8 \\
\hline 1991 & -29 & 2 & 1 & 81 & 6 & 5 & -228 & -7 & -7 \\
\hline 1992 & 45 & 4 & 5 & 176 & 7 & 7 & -168 & -5 & -5 \\
\hline 1993 & 89 & 4 & 4 & 238 & 10 & 9 & -111 & -3 & -3 \\
\hline 1994 & 82 & 5 & 4 & 210 & 8 & 9 & -57 & -2 & -2 \\
\hline 1995 & 147 & 5 & 6 & 236 & 9 & 10 & 0 & 0 & 0 \\
\hline 1996 & 181 & 4 & 7 & 454 & 19 & 17 & 61 & 2 & 2 \\
\hline 1997 & 310 & 9 & 12 & 589 & 24 & 20 & 120 & 3 & 4 \\
\hline 1998 & 377 & 12 & 13 & 546 & 23 & 21 & 177 & 5 & 5 \\
\hline 1999 & 347 & 12 & 11 & 667 & 15 & 19 & 215 & 7 & 7 \\
\hline & 489 & 19 & 15 & 669 & 25 & 24 & 253 & 8 & 8 \\
\hline \multicolumn{10}{|l|}{ All years ${ }^{3}$} \\
\hline Females & -15 & 1 & 1 & & . & $\ldots$ & -195 & -7 & -6 \\
\hline Males & $\ldots$ & $\ldots$ & $\ldots$ & 12 & 2 & 1 & -302 & -11 & -9 \\
\hline
\end{tabular}

${ }^{1}$ Mean of parent PTA.

${ }^{2}$ Registered with Holstein Association USA (Brattleboro, VT).

${ }^{3}$ Means for 921 female and 172 male embryo-split clones; population means are weighted by number of clones of each gender in each year. 
Table 4. Pedigree merit ${ }^{1}$ for yield traits of Holstein nuclear-transfer clones ${ }^{2}$ with USDA-DHIA genetic evaluations by gender and genetic merit (PTA) of the milk-recorded Holstein population by birth year.

\begin{tabular}{|c|c|c|c|c|c|c|c|c|c|}
\hline \multirow[b]{3}{*}{ Birth year } & \multicolumn{6}{|c|}{ Embryo-split clones } & & & \\
\hline & \multicolumn{3}{|c|}{ Females } & \multicolumn{3}{|c|}{ Males } & \multicolumn{3}{|c|}{ Population } \\
\hline & Milk & Fat & Protein & Milk & Fat & Protein & Milk & Fat & Protein \\
\hline & & & & & $-(\mathrm{kg}$ & 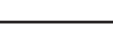 & 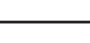 & & - \\
\hline 1989 & -111 & -3 & -2 & -148 & -15 & -6 & -337 & -10 & -10 \\
\hline 1990 & -32 & 4 & 0 & -46 & -5 & -1 & -287 & -8 & -8 \\
\hline 1991 & 37 & 3 & 2 & 177 & 8 & 9 & -228 & -7 & -7 \\
\hline 1992 & 104 & 4 & 3 & & $\ldots$ & & -168 & -5 & -5 \\
\hline 1993 & -29 & 4 & 2 & 232 & 14 & 7 & -111 & -3 & -3 \\
\hline 1994 & $\ldots$ & $\ldots$ & $\ldots$ & $\ldots$ & $\ldots$ & $\ldots$ & -57 & -2 & -2 \\
\hline 1995 & $\ldots$ & & $\ldots$ & $\ldots$ & $\ldots$ & $\ldots$ & 0 & 0 & 0 \\
\hline 1996 & 322 & 16 & 13 & 503 & 3 & 20 & 61 & 2 & 2 \\
\hline 1997 & $\ldots$ & $\ldots$ & $\ldots$ & $\ldots$ & $\ldots$ & $\ldots$ & 120 & 3 & 4 \\
\hline 1998 & $\ldots$ & $\ldots$ & $\ldots$ & $\ldots$ & $\ldots$ & $\ldots$ & 177 & 5 & 5 \\
\hline \multirow{2}{*}{\multicolumn{10}{|c|}{ All years ${ }^{3}$}} \\
\hline & & & & & & & & & \\
\hline Females & 17 & 4 & 2 & $\ldots$ & & $\ldots$ & -190 & -5 & -5 \\
\hline Males & $\ldots$ & $\ldots$ & $\ldots$ & 132 & 0 & 6 & -203 & -6 & -6 \\
\hline
\end{tabular}

dardized yields of milk, fat, and protein (Table 5) were statistically significant $(P \leq 0.001, P \leq 0.01$, and $P \leq$ 0.001 , respectively). Differences for standardized fat percentage, protein percentage, SCS, and PL were not significant $(P>0.05)$. However, 368 of the 608 ETS clones were in herds that were different from those of their full sisters. Therefore, deviations from yields of contemporaries should more accurately reflect differences between ETS clones and full sisters than do standardized yields alone, which are not adjusted for herd environment. Yield deviation for milk, fat, and protein were significant $(P \leq 0.05$ or $P \leq 0.01)$ as well. Even for animals with identical genotypes, phenotypes will vary considerably because of differences in development, environment, and management (Van Vleck, 1999). Full sisters in different herds are expected to have larger differences in yield and fitness records than full sisters in the same herd. More similarity between siblings would be expected for genotype than for phenotype because PA is identical for each ETS clone and its full sibling. Not surprisingly, because of the direct relationship between yield deviations and PTA, PTA were significantly different $(P \leq 0.01$ or $P \leq 0.001)$ for the same traits that had significant phenotypic differences: milk, fat, and protein yields.

Of the 151 ETN female clones that have been registered since 1989, 13 had DHI yield records and noncloned full sisters with records available for comparison (mean of 1.8 full sisters per ETN clone). Nine of the 13 ETN clones were in herds different from those of their 23 full sisters; 6 of the 13 ETN clones were born within
3 mo of their full sisters. None of the phenotypic or genetic differences between ETN clones and their full sisters (Table 5$)$ were statistically significant $(P \leq 0.05)$ when examined with a paired $t$-test, which is not surprising because of the small numbers of animals and thus the low power of the test.

Mean PTA for 82 male clones and their full brothers (mean of 1.3 full brothers per ETS bull) were compared (Table 6). The ETS bulls had mean reliabilities of 0.82 , $0.81,0.61$, and 0.50 for milk and fat, protein, SCS, and PL, respectively, whereas their full brothers had mean reliabilities of $0.84,0.83,0.62$, and 0.53 . Differences in mean PTA between clones and their full brothers were nonsignificant $(P>0.05)$ and extremely small for all traits: only $8 \mathrm{~kg}$ for milk, $1 \mathrm{~kg}$ for fat and protein, 0.1 points for SCS, 0.2 mo for PL, and $0.2 \%$ for DPR, with full brothers favored for all traits except fat and protein percentages, which had equal means.

Male ETS clones that appeared to have identical genotypes (99.8\% probability) had PTA based on daughter yield that were more similar than ETS clones that were confirmed nonidentical through blood typing; i.e., only full brothers (Table 7). Although the clone pairs were not numerous (22 to 25 pairs with likely identical genotypes and 5 to 6 pairs that were not identical), the results were generally as expected. The reliabilities of the two ETS groups for PTA milk were similar at $83 \%$ for identical pairs and $81 \%$ for nonidentical pairs. Differences in PTA within pairs of identical ETS clones were smaller, especially for yield, than within nonidentical pairs. For example, mean absolute difference in 
Table 5. Means of standardized traits, yield deviations, and genetic evaluations for female Holstein embryosplit and nuclear-transfer clones with DHI milk records and their noncloned full sisters with records.

\begin{tabular}{|c|c|c|c|c|}
\hline \multirow[b]{2}{*}{ Trait } & \multicolumn{2}{|c|}{ Embryo split } & \multicolumn{2}{|c|}{ Nuclear transfer } \\
\hline & $\begin{array}{l}\text { Clones }^{1} \\
(\mathrm{n}=608)\end{array}$ & $\begin{array}{l}\text { Full sisters }{ }^{2} \\
\left(\overline{\mathrm{n}} / \text { clone }^{\prime}=1.7\right)\end{array}$ & $\begin{array}{l}\text { Clones }^{3} \\
(\mathrm{n}=13)\end{array}$ & $\begin{array}{l}\text { Full sisters }{ }^{2} \\
\left(\overline{\mathrm{n}} / \text { clone }^{\prime} 1.8\right)\end{array}$ \\
\hline \multicolumn{5}{|l|}{ Standardized trait } \\
\hline Milk, kg & 10,716 & $11,016 * * *$ & 10,456 & 10,715 \\
\hline Fat, kg & 394 & $402 * *$ & 379 & 389 \\
\hline Fat, $\%$ & 3.68 & 3.65 & 3.62 & 3.63 \\
\hline Protein, kg & 320 & $329 * * *$ & 326 & 325 \\
\hline Protein, \% & 2.99 & 2.99 & 3.11 & 3.03 \\
\hline SCS & 3.1 & 3.1 & 3.6 & 3.0 \\
\hline Productive life, mo & 25.7 & 26.4 & 23.1 & 26.7 \\
\hline \multicolumn{5}{|c|}{ Yield deviation from contemporaries } \\
\hline Milk, kg & -199 & $3 * *$ & -278 & -305 \\
\hline Fat, kg & -2 & $3^{*}$ & -17 & -13 \\
\hline Protein, kg & -3 & $2^{* *}$ & -2 & -7 \\
\hline \multicolumn{5}{|l|}{ PTA } \\
\hline Milk, kg & -37 & $-1 * *$ & -18 & 9 \\
\hline Fat, kg & 1 & $2 * *$ & -3 & 0 \\
\hline Fat, \% & 0.02 & 0.02 & -0.02 & 0.00 \\
\hline Protein, kg & 0 & $1^{* * *}$ & 2 & 2 \\
\hline Protein, \% & 0.01 & 0.01 & 0.02 & 0.02 \\
\hline SCS & 3.08 & 3.09 & 3.18 & 3.15 \\
\hline Productive life, mo & 0.1 & 0.2 & -0.6 & -0.4 \\
\hline Daughter pregnancy rate, $\%$ & 0.1 & 0.1 & -0.2 & -0.1 \\
\hline
\end{tabular}

${ }^{1}$ Records from 368 of the 608 embryo-split clones were from herds different from the records of their full sisters.

${ }^{2}$ Level of statistical significance indicated for difference between clones and full sisters; all differences between nuclear-transfer clones and full sisters were nonsignificant $(P>0.05)$.

${ }^{3}$ Records from 9 of the 13 nuclear-transfer clones were from herds different from the records of their full sisters; 6 of the 13 clones were born within 3 mo of their full sisters.

$* P \leq 0.05$.

$* * P \leq 0.01$

$* * * P \leq 0.001$.

PTA milk for identical ETS clones was $121 \mathrm{~kg}$ with a standard deviation of $111 \mathrm{~kg}$, whereas that for ETS full brothers was $223 \mathrm{~kg}$ with a standard deviation of 222 $\mathrm{kg}$. Correlations for PTA of yield traits were higher for identical ETS pairs: 0.87 to 0.92 (compared with 0.35

Table 6. Mean genetic evaluations for male Holstein embryo-split clones and their noncloned full brothers with evaluations.

\begin{tabular}{lcc}
\hline Trait & $\begin{array}{c}\text { Clones } \\
(\mathrm{n}=82)\end{array}$ & $\begin{array}{c}\text { Full brothers }{ }^{1} \\
(\overline{\mathrm{n}} / \mathrm{clone}=1.3)\end{array}$ \\
\hline PTA & & \\
Milk, kg & -86 & -78 \\
Fat, kg & 0 & 1 \\
Fat, \% & 0.03 & 0.03 \\
Protein, kg & -2 & -1 \\
Protein, \% & 0.01 & 0.01 \\
SCS & 3.2 & 3.1 \\
Productive life, mo & -0.5 & -0.3 \\
Daughter pregnancy rate, $\%$ & 0.0 & 0.2 \\
Daughters, no. & 139 & 223 \\
Herds with daughters, no. & 77 & 116 \\
\hline
\end{tabular}

${ }^{1}$ Difference between male clones and full brothers was nonsignificant $(P>0.05)$ for all traits. to 0.72 for nonidentical ETS pairs). Absolute differences in PTA for the three fitness traits (SCS, PL, and DPR) also were smaller for identical ETS clones than for nonidentical pairs, and correlations for PTA of fitness traits were higher by 0.04 to 0.28 . Absolute differences in PTA should be smaller and correlations between PTA should be higher for identical ETS clones than for nonidentical pairs because the expectations for identical pairs are nearly equal to those for two independent progeny tests of the same bull.

Differences in daughter deviations followed the same pattern as for PTA differences (Table 7). Correlations for daughter deviations were substantially higher for identical ETS pairs than for nonidentical pairs for all traits except DPR and ranged from 0.54 for PL to 0.93 for SCS compared with -0.03 for PL to 0.74 for protein yield; for DPR, daughter deviation correlation was 0.42 for identical pairs and 0.46 for nonidentical pairs. Expected correlations (mean square root of product of daughter reliabilities for pair; not shown in table) for identical genotypes were 0.78 for milk, fat, and protein 
Table 7. Absolute differences and correlations between daughter deviations of genetically identical and nonidentical pairs of male Holstein embryo-split clones and between their PTA.

\begin{tabular}{|c|c|c|}
\hline Trait & Identical pairs & Nonidentical pairs \\
\hline \multicolumn{3}{|l|}{ Animal pairs (no.) } \\
\hline Yield (milk, fat, protein) & 25 & 6 \\
\hline SCS & 22 & 5 \\
\hline Productive life & 23 & 6 \\
\hline Daughter pregnancy rate & 22 & 5 \\
\hline \multicolumn{3}{|c|}{ Absolute PTA difference (mean \pm SD) } \\
\hline Milk, kg & $121 \pm 111$ & $223 \pm 222$ \\
\hline Fat, kg & $4.2 \pm 4.0$ & $13.5 \pm 6.6$ \\
\hline Protein, kg & $3.4 \pm 3.1$ & $7.0 \pm 5.1$ \\
\hline SCS & $0.06 \pm 0.07$ & $0.10 \pm 0.09$ \\
\hline Productive life, mo & $0.7 \pm 0.5$ & $0.8 \pm 0.4$ \\
\hline Daughter pregnancy rate, $\%$ & $0.52 \pm 0.39$ & $0.64 \pm 0.38$ \\
\hline \multicolumn{3}{|l|}{ Reliability (mean \pm SD) } \\
\hline Milk, fat & $0.83 \pm 0.11$ & $0.81 \pm 0.07$ \\
\hline Protein & $0.83 \pm 0.11$ & $0.80 \pm 0.07$ \\
\hline SCS & $0.68 \pm 0.12$ & $0.63 \pm 0.09$ \\
\hline Productive life & $0.67 \pm 0.12$ & $0.61 \pm 0.06$ \\
\hline Daughter pregnancy rate & $0.67 \pm 0.11$ & $0.62 \pm 0.06$ \\
\hline \multicolumn{3}{|l|}{ PTA correlation ${ }^{1}$} \\
\hline Milk & $0.87 * * *$ & 0.68 \\
\hline Fat & $0.90 * * *$ & 0.35 \\
\hline Protein & $0.92 * * *$ & 0.72 \\
\hline SCS & $0.88 * * *$ & 0.84 \\
\hline Productive life & $0.70 * * *$ & 0.42 \\
\hline Daughter pregnancy rate & $0.79 * * *$ & 0.55 \\
\hline \multicolumn{3}{|c|}{ Absolute daughter deviation difference $($ mean $\pm \mathrm{SD})$} \\
\hline Milk, kg & $151 \pm 145$ & $256 \pm 253$ \\
\hline Fat, kg & $5.0 \pm 4.9$ & $17.0 \pm 8.4$ \\
\hline Protein, kg & $4.1 \pm 3.7$ & $8.7 \pm 5.1$ \\
\hline SCS & $0.08 \pm 0.06$ & $0.15 \pm 0.13$ \\
\hline Productive life, mo & $1.6 \pm 1.0$ & $1.9 \pm 1.6$ \\
\hline Daughter pregnancy rate, $\%$ & $1.26 \pm 0.99$ & $1.41 \pm 0.84$ \\
\hline \multicolumn{3}{|l|}{ Daughter reliability (mean \pm SD) } \\
\hline Milk, fat & $0.78 \pm 0.18$ & $0.76 \pm 0.12$ \\
\hline Protein & $0.78 \pm 0.18$ & $0.75 \pm 0.11$ \\
\hline SCS & $0.57 \pm 0.19$ & $0.49 \pm 0.16$ \\
\hline Productive life & $0.56 \pm 0.21$ & $0.45 \pm 0.13$ \\
\hline Daughter pregnancy rate & $0.54 \pm 0.18$ & $0.47 \pm 0.12$ \\
\hline \multicolumn{3}{|l|}{ Daughter deviation correlation ${ }^{1}$} \\
\hline Milk & $0.82 * * *$ & 0.65 \\
\hline Fat & $0.87 * * *$ & 0.19 \\
\hline Protein & $0.89 * * *$ & 0.74 \\
\hline SCS & $0.93 * * *$ & 0.68 \\
\hline Productive life & $0.54 * *$ & -0.03 \\
\hline Daughter pregnancy rate & 0.42 & 0.46 \\
\hline
\end{tabular}

${ }^{1}$ Level of statistical significance indicated for difference of correlation from 0 .

$* * P \leq 0.01$.

$* * * P \leq 0.001$.

yields; 0.77 for SCS; 0.56 for PL; and 0.55 for DPR. Surprisingly, the pairs of nonidentical ETS full brothers were more highly correlated for DPR daughter deviation than were identical ETS bull pairs (in contrast to correlations for PTA DPR), but the daughter deviation correlation was not significantly different from $0(P>$ 0.05 ) for either group of bull pairs. The greater uniformity among nonidentical full brothers in daughter deviation for DPR is unlikely to be sustained as more pairs are added.

\section{CONCLUSIONS}

Numbers of clones have decreased for ETS and ETN male clones. Animals selected for cloning were slightly superior genetically for yield traits to the population. Yields of ETN clones were slightly lower, although not significantly different $(P>0.05)$ from those of their noncloned full siblings. Yields of ETS clones also were slightly less than those of their full siblings and highly significant $(P \leq 0.01)$, which could indicate either an 
impact of the technology on performance or reflect differences in management across the two groups. Composition of milk from cloned cows as determined by component (fat and protein) percentages and SCS was not different from that of the milk-recorded US Holstein population. Male clone pairs with apparent identical genotype (99.8\% probability) had PTA based on daughter yields that were more similar than those for male pairs from the same biotechnology but that were confirmed by blood typing to be nonidentical. For ETS clones that are confirmed to have identical genotypes, an identical PTA should be assigned when calculating genetic evaluations. A decision on whether to change the method of calculating genetic evaluations for ETN animals should be deferred until more observations are available.

\section{ACKNOWLEDGMENTS}

This research was initiated at the request of Amey Adams and Cindy Burnsteel of the U.S. Department of Health and Human Services, Food and Drug Administration, Center for Veterinary Medicine. The assistance of Irma Robinson and Martin Church of Holstein Association USA, Brattleboro, VT, in supplying clone coding is appreciated. The assistance of Linda Mooney, Animal Improvement Programs Laboratory, Beltsville, MD, in determining the genetic relationship among cloned males is acknowledged, as well as the assistance of Suzanne Hubbard in figure preparation and manuscript review.

\section{REFERENCES}

Center for Veterinary Medicine, Food and Drug Administration. 2001. Update on livestock cloning. Online: http://www.fda.gov/cvm/ index/updates/clones.htm. Accessed Dec. 11, 2003.

Committee on Defining Science-Based Concerns Associated with Products of Animal Biotechnology, Board on Agriculture and Natural Resources, National Research Council. 2002. Animal Biotechnology: Science-Based Concerns. National Academies Press, Washington, DC. Online: http://www.nap.edu/books/0309084393/ html. Accessed Dec. 11, 2003.

Echternkamp, S. E., and K. E. Gregory. 2002. Reproductive, growth, feedlot, and carcass traits of twin vs single births in cattle. J. Anim. Sci. 80(E. Suppl. 2):E64-E73. Online: http://www.asas.org/ jas/symposia/esupp2/jas2051.pdf. Accessed Dec. 11, 2003.

ImmGen, Inc. 2001. About blood typing. Online: http://www.immgen. com/Services/Verification/Bloodtyping.html. Accessed Dec. 11, 2003.

Robl, J. M., R. Prather, F. Barnes, W. Eyestone, D. Northey, B. Gilligan, and N. L. First. 1987. Nuclear transplantation in bovine embryos. J. Anim. Sci. 64:642-647.

VanRaden, P. M., A. H. Sanders, M. E. Tooker, R. H. Miller, and H. D. Norman. 2002. Daughter pregnancy rate evaluation of cow fertility. AIPL Res. Rep. DPR1(11-02). Online: http://aipl.arsusda. gov/docs/reference/fertility/DPR rpt.htm. Accessed Dec 11, 2003.

Van Vleck, L. D. 1999. Implications of cloning for breed improvement strategies: are traditional methods of animal improvement obsolete? J. Anim. Sci. 77/J. Dairy Sci. 82( Suppl. 2):111-121.

Willadsen, S. M. 1979. A method for culture of micromanipulated sheep embryos and its use to produce monozygotic twins. Nature 277:298-300.
Young, L. E., K. D. Sinclair, and I. Wilmut, 1998. Large offspring syndrome in cattle and sheep. Rev. Reprod. 3:155-163.

\section{APPENDIX: IDENTIFICATION OF ANIMALS WITH IDENTICAL GENOTYPES}

Blood typing often is performed to verify parentage and to provide information about genetic similarity. Blood typing allows the development of an animal profile using immunological tests, and the uniqueness of that profile can be assessed based on the rules of inheritance. The blood typing that is required by Holstein Association USA involves testing for 11 blood systems (A, B, C, F, J, L, M, S, R', T', and Z). Each of those blood systems is located on separate chromosome pairs and has two phenogroups: one for each chromosome of the pair (ImmGen, Inc., 2001).

The probability of detecting that two full siblings are not identical genetically (an exclusion) within phenogroup i $\left[P\left(\mathrm{E}_{\mathrm{i}}\right)\right]$ is:

$$
P\left(\mathrm{E}_{\mathrm{i}}\right)=\sum_{\mathrm{j}=1}^{5} P\left(\mathrm{M}_{\mathrm{ij}}\right)\left[P\left(\mathrm{E}_{\mathrm{ij}} \mid \mathrm{M}_{\mathrm{ij}}\right)\right],
$$

where $P\left(\mathrm{M}_{\mathrm{ij}}\right)=$ probability of occurrence of parental mating type $\mathrm{j}$ within phenogroup $\mathrm{i}$ and $P\left(\mathrm{E}_{\mathrm{ij}} \mid \mathrm{M}_{\mathrm{ij}}\right)=$ probability of detecting an exclusion given mating type $j$ within phenogroup $i$. The five parental mating types are described in Table A1.

The probability of a mating between parents with a specific set of genotypes can be determined using a Punnett Square and calculating the possible progeny genotypes from parents with different genotypes. For $\mathrm{n}$ alleles, there are $\mathrm{n}^{2}$ parental genotypes and $\mathrm{n}^{4}$ mating combinations. An illustration of the calculations involved is in Table A1 using phenogroup A as an example. Phenogroup A has four alleles with a frequency of 0.13 for $\mathrm{A} 1,0.15$ for $\mathrm{A} 2,0.15$ for $\mathrm{A} 3$, and 0.57 for $\mathrm{A} 4$. The probability of detecting nonidentical siblings through phenogroup A $\left[P\left(\mathrm{E}_{\mathrm{A}}.\right)\right]$ is 0.5085 . Phenogroups with greater numbers of alleles are usually more helpful in revealing exclusions. A spreadsheet for a single locus with up to 17 alleles is available from the second author.

Informative matings have at least one heterozygous parent. The probability of a mating involving at least one heterozygous parent and the probability of detecting an exclusion are shown in Table A2 for all phenogroups. The cumulative joint probability of detecting an exclusion $[P(\mathrm{E} .)$.$] is$

$$
P\left(\mathrm{E}_{. .}\right)=\left(1-\prod_{\mathrm{i}=1}^{\mathrm{n}}\left[1-P\left(\mathrm{E}_{\mathrm{i} .}\right)\right]\right),
$$

where $P\left(\mathrm{E}_{\mathrm{i}}\right)=$ probability of detecting an exclusion from phenogroup i. Therefore, the probability of detecting nonidentical siblings based on the 11 blood phenogroups that are typed for Holsteins is 0.998 . 
Table A1. Parental mating genotypes using phenogroup A as an example, ${ }^{1}$ their frequency of occurrence $\left[P\left(\mathrm{M}_{\mathrm{Aj}}\right)\right]$, the probability of detecting nonidentical genotypes (an exclusion) given that type of mating $\left[P\left(\mathrm{E}_{\mathrm{Aj}} \mid \mathrm{M}_{\mathrm{Aj}}\right)\right]$, and the probability of finding an exclusion through that type of mating $\left[P\left(\mathrm{E}_{\mathrm{Aj}}\right)\right]$.

\begin{tabular}{lllll}
\hline Parental mating genotypes & $\begin{array}{l}\text { Phenogroup A } \\
\text { example }\end{array}$ & $P\left(\mathrm{M}_{\mathrm{Aj}}\right)$ & $P\left(\mathrm{E}_{\mathrm{Aj}} \mid \mathrm{M}_{\mathrm{Aj}}\right)$ & $P\left(\mathrm{E}_{\mathrm{Aj}}\right)$ \\
\hline Two homozygotes & $\mathrm{A} 1 \mathrm{~A} 1, \mathrm{~A} 2 \mathrm{~A} 2$ & 0.1496 & 0.000 & 0.0000 \\
One homozygote, one heterozygote & $\mathrm{A} 1 \mathrm{~A} 1, \mathrm{~A} 2 \mathrm{~A} 3$ & 0.4744 & 0.500 & 0.2372 \\
Two heterozygotes, same alleles & $\mathrm{A} 1 \mathrm{~A} 2, \mathrm{~A} 1 \mathrm{~A} 2$ & 0.0855 & 0.625 & 0.0534 \\
Two heterozygotes, one different allele & A1A2, A1A3 & 0.2505 & 0.750 & 0.1879 \\
Two heterozygotes, two different alleles & A1A2, A3A4 & 0.0400 & 0.750 & 0.0300 \\
\hline
\end{tabular}

${ }^{1}$ Phenogroup A has four alleles with the following frequencies: 0.13 for A1, 0.15 for A2, 0.15 for A3, and 0.57 for A4.

Table A2. Blood phenogroups used to detect nonidentical genotypes for registered Holstein full siblings, probability of a mating with at least one heterozygous parent, and probability of detecting nonidentical genotypes based on such a mating for that phenogroup $\left[P\left(\mathrm{E}_{\mathrm{i} .}\right)\right]$.

\begin{tabular}{|c|c|c|c|c|c|c|}
\hline \multirow[b]{2}{*}{ Phenogroup } & \multirow[b]{2}{*}{$\begin{array}{l}\text { Total } \\
\text { alleles }\end{array}$} & \multicolumn{3}{|c|}{ Alleles with population frequency of $\geq 0.01$} & \multirow{2}{*}{$\begin{array}{l}\text { Probability of } \\
\text { a mating with } \\
\text { at least one } \\
\text { heterozygous parent }\end{array}$} & \multirow[b]{2}{*}{$P\left(\mathrm{E}_{\mathrm{i} .}\right)$} \\
\hline & & Number & $\begin{array}{l}\text { Minimum } \\
\text { frequency }\end{array}$ & $\begin{array}{l}\text { Maximum } \\
\text { frequency }\end{array}$ & & \\
\hline A & 4 & 4 & 0.13 & 0.57 & 0.8504 & 0.5085 \\
\hline B & 103 & 17 & 0.01 & 0.25 & 0.9875 & 0.6897 \\
\hline $\mathrm{C}$ & 79 & 13 & 0.01 & 0.20 & 0.9808 & 0.6719 \\
\hline $\mathrm{F}$ & 2 & 2 & 0.12 & 0.88 & 0.3778 & 0.1945 \\
\hline $\mathrm{J}$ & 2 & 2 & 0.28 & 0.72 & 0.6438 & 0.3422 \\
\hline $\mathrm{L}$ & 2 & 2 & 0.23 & 0.77 & 0.5829 & 0.3072 \\
\hline $\mathrm{M}$ & 3 & 2 & 0.01 & 0.99 & 0.0392 & 0.0197 \\
\hline $\mathrm{S}$ & 11 & 6 & 0.05 & 0.41 & 0.9190 & 0.5766 \\
\hline $\mathrm{R}^{\prime}$ & 3 & 2 & 0.01 & 0.99 & 0.0392 & 0.0197 \\
\hline $\mathrm{T}^{\prime}$ & 2 & 2 & 0.14 & 0.86 & 0.4236 & 0.2191 \\
\hline $\mathrm{Z}$ & 3 & 2 & 0.21 & 0.79 & 0.5535 & 0.2905 \\
\hline
\end{tabular}

